\title{
THE ROLE OF MUTAWWIF AS A MODERATION IN IMPROVING THE LOYALTY OF THE PILGRIM: STUDY IN PT. AL-MABRUR ACEH
}

\author{
*Abdul Muthalib Buchari, Mukhlis and Said Musnadi \\ Management Department, Universitas Syiah Kuala, 23111, Indonesia
}

$\underline{\text { http://doi.org/10.35409/IJBMER.2020.3166 }}$

\begin{abstract}
This study examines the effect of exploring the role of mutawwif in moderating the influence of travel agent credibility, price and service quality in increasing the loyalty of pilgrims with pilgrim satisfaction as an intervening variable. The population is all pilgrims at PT. Al-Mabrur Aceh during 2016 to 2018 a number of 771 people, and the sampleis taken based on the method of Maximum Like hood Estimation so it provides 200 respondents. The research model is analyzed using Structural Equation Modeling (SEM), using Amos software. The resuls proves that travel agent credibility has a significant effect on pilgrim satisfaction, price has a significant effect on pilgrim satisfaction, service quality has a significant effect on pilgrim satisfaction, satisfaction has a significant effect on the loyalty of pilgrims, travel agent credibility has a significant effect on pilgrim loyalty, price has no significant effect on pilgrim loyalty, Service quality has a significant effect on pilgrim loyalty, there is an indirect effect of travel agent credibility on the loyalty of pilgrims through the satisfaction of pilgrims, on the indirect effect of prices on the loyalty of pilgrims through pilgrimage satisfaction, there is an indirect influence on the quality of service of pilgrims loyalty through pilgrim satisfaction, and Mutawwif becomes a predictor that moderates the effect of the travel agent credibility and service quality of the loyalty of pilgrims at PT. Al-Mabrur Aceh. These findings contribute academically, especially in the renewal of the causality theories and can be a reference for practical leaders, especially those in PT. Al-Mabrur Aceh. The novelty of this research lies in the combination of previous causality research models, with a new object. The limitation of the study is the number of variables studied and the scope of the study.
\end{abstract}

Keyword: Travel Agency Credibility, Price, Service Quality, Pilgrim Satisfaction, Mutaww if Role, Pilgrim Loyalty.

\section{INTRODUCTION}

Indonesia is a country with a majority Muslim population, the largest in the world. Every Muslim certainly wants to be able to worship properly and correctly according to guidance as what Allah has said in the Qur'an and Hadith. The main points of worship contained in the pillars of Islam. Of the five pillars of Islam, of course for every Muslim in the world have aspirations to fulfill the fifth pillar of Islam that is performing the pilgrimage. But to perform the pilgrimage, it is not necessarily easy. This is due to the large number of prospective pilgrims who have 


\section{International Journal of Business Management and Economic Review}

Vol. 3, No. 02; 2020

ISSN: 2581-4664

registered and exceed the capacity determined by the government each year. The waiting period for the time of Hajj departure reaches between 20 to 25 years from the date of registration.

Until 2019 the number of Aceh pilgrims who had registered to leave for the hajj was 100,062,541 people (Ministry of Religion in Aceh, January; 2019). Considering the number of pilgrims and the length of the Hajj departure process, the majority of Muslims who have the sufficient economy choose Umrah as an alternative. Umrah worship is a worship service which is not directly handled by the government. This opportunity is utilized by private transportation bureaus by organizing the Umrah program by providing facilities for the convenience of Umrah worship. In Aceh there are 14 Umrah Travels that have obtained a permit from the Ministry of Religion in Aceh.

Seeing the high growth of the Umrah service bureau business today, this business is no longer just a business selling services but has reached the environment and comfort. With the large number of bureaus, it is natural that fierce competition arises to find consumers and retain existing customers or worshipers. In carrying out the program of Umrah\& Hajj, the pilgrims are of course guided from the beginning of the departure through menasik and to the destination and return by the guide or in other words mutawwif.

In the science of marketing management mutawwif or people are interpreted as all actors who play an important role in the presentation of services so that they can influence the perception of buyers. All employee attitudes and actions, employee attire and appearance have an influence on the success of service delivery(Kotler \& Keller, 2018). Tourists will experience satisfaction through effective interpretation by high-quality tour guides. This interaction between people and their environment leads to pleasure and cognitive absorption (which includes concentration and curiosity)(Oh, Jeong, \& Baloglu, 2013). This result also explained that tourist guides in this case mutawwif can strengthen the relationship of service quality perceived by pilgrims to pilgrim loyalty. To maintain this, every service company especially Umrah travel agency must have a good strategy in maintaining the loyalty of its pilgrims so they do not run elsewhere. Consumer loyalty will arise if consumers are satisfied with the services provided(Kotler \& Keller, 2009). But there is something unique in customer satisfaction, because customer satisfaction is dynamic, one's level of satisfaction with a product or service is always changing from time to time. So in this case, to increase consumer satisfaction in order to maintain the loyalty of pilgrims, the service quality factor must be improved. Not only is the quality of service expected by pilgrims, but price fixing also greatly determines customer satisfaction in the use of Hajj and Umrah services. Price also plays an important role in building customer loyalty(Adams, Highhouse, \& Zickar, 2010).

The incident failed to go to Umrah until the fraud by the Umrah travel agency lately increasingly widespread, making many prospective pilgrims and andUmrah has opened wide eyes in choosing the Hajj and Umrah travel agency. This is caused by fraud at low prices. This fanomena has an impact on the implementation of other worship services that perform good and right services in accordance with the provisions in force in the Department of Religion as has also been applied to the Hajj and Umrah Travel Bureau of PT. Al-Mabrur Aceh. Hajj and Umrah Travel Bureau PT. Al-Mabrur Aceh experienced fluctuating growth in the number of pilgrim and umrah each year. Besides being caused by the phenomenon mentioned above, the cause of fluctuation is also caused by the level of competition with other Umrah traversers. The tariff war (the price of the Umrah package) ensued with various terms "Cheap packages", "Thrifty 


\section{International Journal of Business Management and Economic Review}

Vol. 3, No. 02; 2020

ISSN: 2581-4664

packages", "Economical Packages" regardless of the service, satisfaction and specificity of the Worship of the Pilgrims.

\section{LITERATURE STUDY \\ Mutawwif(people)}

Mutawwif means the person who is doing tawaf or going around the Kaaba. However, at this time mutawwif became a term for people who became guides or guides of the Hajj and Umrah pilgrimage(Jauhary, 2014).In his book(Priansa, 2017)mention people are people who give consumers perceptions about the quality of the services they have bought in the company, so that it affects the process of purchasing the services concerned. People have a role in service that can influence buyer perception; namely company personnel, customers, and other customers in the service environment(Zeithaml, Bitner, \& Gremler, 2018).

According to(Simamora, 2004), measuring people can be done by using the following indicators: (1) Competence; (2) Courtesy; (3) Selective; and (4) Communicative.

\section{Pilgrim Loyalty (Customers)}

According to(Ramli \& Sjahruddin, 2015)customer loyalty is the customer's commitment to persevere in depth to re-subscribe or repurchase consistently selected goods / services in the future, even though the influence of the situation and marketing efforts have the potential to cause changes in desired behavior. Companies must create and maintain customer loyalty, which can increase the number of purchases, reduce operating costs, lower prices, reduce the cost of getting new customers in the long run(Bachri, Lubis, Nurdasila, \& Majid, 2016).

According to(Hermawan, Basalamah, Djamereng, \& Plyriadi, 2017); (Griffin, 2005)service quality is measured by five items namely; (1) repurchase, (2) indifference to the negative influence on the product, (3) recommending to others (4) customer trust when using the product, and (5) Not easily affected by persuasion or competitor sales.

\section{Pilgrim Satisfaction (Customers)}

Consumer satisfaction according to(Tjiptono, 2017)can be interpreted as an effort to fulfill something or make something adequate. Satisfaction is defined as feeling happy or disappointed when a customer compares the performance of a product that is felt with previous expectations. Obviously customer satisfaction is a post-decision experience(Jiang \& Zhang, 2016). According to(Kotler \& Keller, 2018)customer satisfaction depends on the performance of the product assumption relative to buyer expectations. If product performance does not meet expectations, the customer is disappointed. Satisfied consumers will produce benefits for the company, which refers to an important element in improving business performance(Bachri et al., 2016).

Expectation-Disconfirmation Theory is the theory that underlies customer satisfaction. Satisfaction is the difference in meeting the needs and desires of the continuing gap between the desired goals(Ramli \& Sjahruddin, 2015). Expectation-Confirmation Theory is the theory that underlies customer satisfaction. Satisfaction is the difference in meeting the needs and desires of the continuing gap between the desired goals. According to(Kotler \& Keller, 2018)customer satisfaction is measured by: (1) buying again; (2) say good things about the company to others and recommend it; (3) paying less attention to brands and advertisements of competing products; 


\section{International Journal of Business Management and Economic Review}

Vol. 3, No. 02; 2020

ISSN: 2581-4664

(4) buy other products from the same company; (5) offer product ideas or services to companies.

\section{Travel Agent credibility}

Credibility is defined as quality, capability, or strength to generate trust.(Halim \& Suryani, 2013).Credibility will be reflected in the agent's knowledge or understanding of the services offered, agent openness, and agent's ability to deal with pilgrims' problems. Credibility is considered important for the company because credibility is related to the trust of a pilgrim in agents and companies. Credibility is a key driver of a company's reputation, which refers to consumers to believe that companies can create and deliver products and services that satisfy consumer desires(Bachri et al., 2016).

Several indicators of the agent's credibility revealed by(Shimp, 2013)yaitu: (1) Integriti, (2) expertise, (3) trusworthiness, (4) Attractivennes, and (5) power.

\section{Price}

Price has a large influence in determining a product because price is one of the attributes in consumer decision making. According to (Kotler \& Keller, 2018)price is the amount of money billed for a product or service. More broadly, price is the sum of all values given by customers to benefit from owning or using a product or service. According to(Tjiptono, 2017)prices can be expressed in various terms, such as fees, rates, rent, interest, premiums, commissions, wages, salaries, honoriums, SPP and so on. From a marketing point of view price is a monetary or other measure (including other goods and services) exchanged in order to obtain ownership or use rights of an item or service. Consumers in assessing prices, have a strong influence on purchase intentions and satisfaction. Some price indicators expressed by(Kotler \& Keller, 2012)namely: (1) Price performance, (2) Price according to ability or price competitiveness, (3) price conformity with product quality, (4) price match with benefits, and (5) Attractive Bonus.

\section{Kualitas Pelayanan}

The quality of the services provided is very closely related to the satisfaction felt by the customer. (Wijaya, 2018)explained that service quality is a measure of how good the level of service that has been given is able to match customer expectations or according to the needs and desires of the customer. Service quality is centered on efforts to meet the needs and desires of consumers and the accuracy of its delivery to balance consumer expectations, namely by the conformity between expectations and management perceptions, conformity between perceptions of consumer expectations with employee work standards, suitability between employee work standards and services provided with services promised and the suitability between the service received and expected with consumers (Sunyoto, 2012).

Several service quality indicators are expressed by(Parasuraman, Zeithaml, \& Berry, 1988)namely: (1) Costs and services; (2) Facilities; (3) Appearance of officers; (4) Service procedures; (5) Settlement time; (6) Officer responsiveness; (7) Emotional Relationship; (8) Company attention to staff knowledge; (9) officers' attention to customers; (10) Understand the customer's problems.

\section{Research paradigm}

Based on the discussion of the problem and research literature, the researcher formulates the 
Vol. 3, No. 02; 2020

ISSN: 2581-4664

paradigm and research hypothesis as follows.

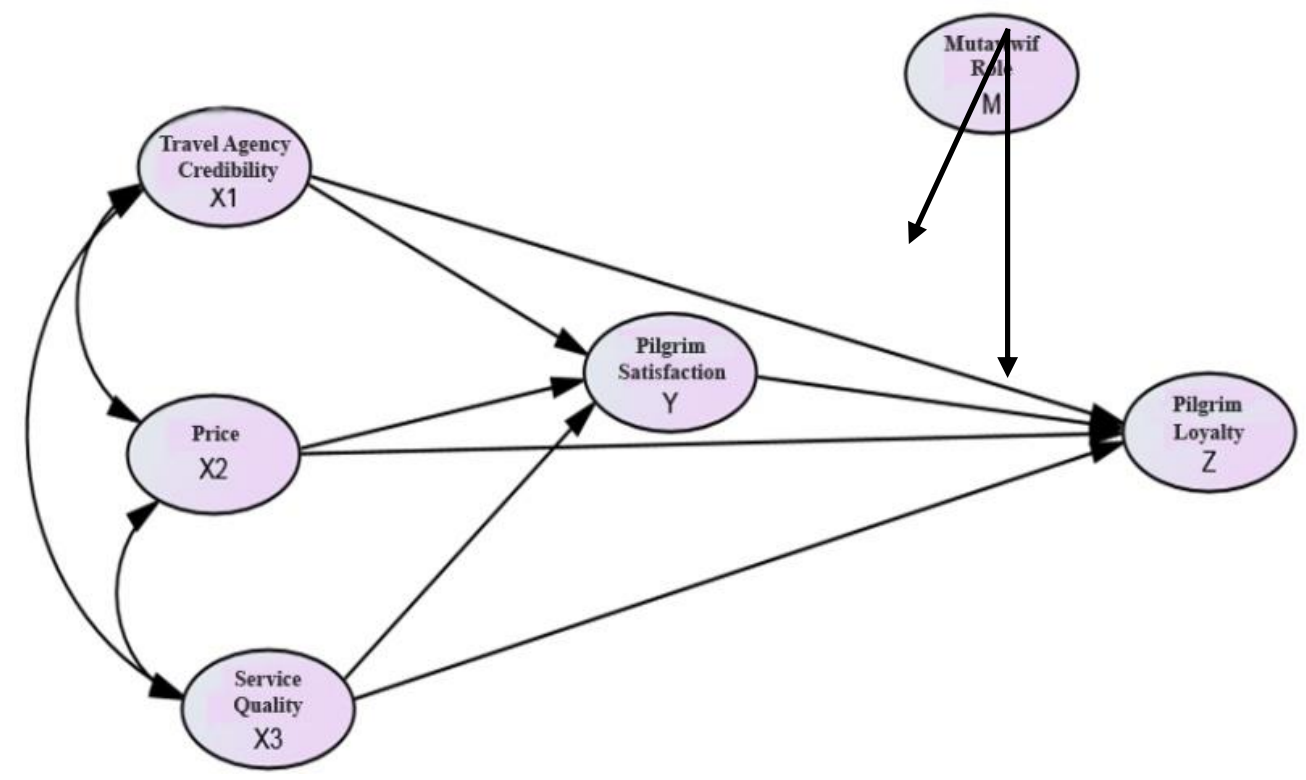

Figure 1. Research Model

H1 : Travel agent credibility influences pilgrim satisfaction

$\mathrm{H} 2$ : Price affects pilgrim satisfaction

$\mathrm{H} 3$ :: Service quality affects pilgrim satisfaction

$\mathrm{H} 4$ :: Pilgrim satisfaction affects the loyalty of pilgrim

H5 : Travel agent credibility influences pilgrimloyalty

H6 : Price affects pilgrimloyalty

H7 : Service Quality affects pilgrimloyalty

H8 : Travel agent credibility affects pilgrimloyalty through pilgrimsatisfaction.

H9: Price affectspilgrim loyalty through pilgrim satisfaction

H10 : Service quality affects pilgrim loyalty through pilgrim satisfaction

H11: Mutawwif moderates the effect of travel agent credibility on pilgrimloyalty

H12 : Mutawwif moderates the effect of service quality on pilgrim loyalty

\section{RESEARCH METHOD}

This research is conducted at the Hajj and Umrah Travel Bureau PT. Al-Mabrur Aceh. while the object of research is Travel Agent Crediblity, Price, Service Quality, Pilgrim Satisfaction and Pilgrim Loyalty and Mutawwif Role as moderator.

The study population is pilgrims at PT. Al-Mabrur Aceh during 2016 to 2018 as many as 771 people. The sampling technique uses the Maximum Likehood Estimation method. (F. Hair Jr, Sarstedt, Hopkins, \& G. Kuppelwieser, 2014)stated the ideal number of respondents for the use of Maximum Likehood Estimation is that the sample taken based on the Maximum Likehood Estimation method in the structural equation model is around 100-200 respondents. So, the 


\section{International Journal of Business Management and Economic Review}

Vol. 3, No. 02; 2020

ISSN: 2581-4664

sample that is taken from the population in this study is as much as 200 respondents.

Data is collected using a questionnaire. The list of questions is asked and assessed using a Likert scale. Data analysis equipment used in this study was Structural Equation Modeling (SEM) using Amos software. The SEM equation model is a collection of statistical techniques that allow the simultaneous testing of a series of relatively complex relationships(Hair, Hult, Ringle, \& Sarstedt, 2016).SEM is able to enter latent variables into the analysis. Before testing the hypothesis, confirmatory factor analysis (CFA). CFA in SEM needs to be done to ensure that the indicators are fit(Silva \& Alwi, 2008). To test mediation variables, this study uses the Sobel test.

In this study, researchersbulid constructs for each variable studied based on previous theories, and the conditions that bind the measurement of organizational performance under study, namely:

a) Mutawwif with measurement indicators (1) Competence; (2) Courtesy; (3) Selective; and (4) Communicative.

b) Pilgrim loyalty with measurement indicators (1) repurchase, (2) indifference to the negative influence on the product, (3) Recommending to others (4) customer trust when using the product, and (5) Not easily influenced by persuasion or sales competitor.

c) Pilgrim satisfaction with measurement indicators (1) buy again; (2) say good things about the company to others and recommend it; (3) paying less attention to brands and advertisements of competing products; (4) buy other products from the same company; (5) offer product ideas or services to companies.

d) Travel agent credibility with measurement indicators (1) integrity, (2) Expertise, (3) Trustworthiness, (4) Attractiveness, and (5) power.

e) Prices with measurement indicators (1) Price Delay, (2) Prices according to ability or price competitiveness, (3) price conformance with product quality, (4) suitability of prices with benefits, and (5) Attractive Bonuses.

f) Service quality with measurement indicators (1) Costs and services; (2) Facilities; (3) Appearance of officers; (4) Service procedures; (5) Settlement time; (6) Officer responsiveness; (7) Emotional Relationship; (8) Company attention to staff knowledge; (9) officers' attention to customers; (10) Understand the customer's problems.

\section{RESULTS AND DISCUSSION}

Structural model analysis that explains the test of influence between variables is presented in the following path diagram: 


\section{International Journal of Business Management and Economic Review}

Vol. 3, No. 02; 2020

ISSN: 2581-4664

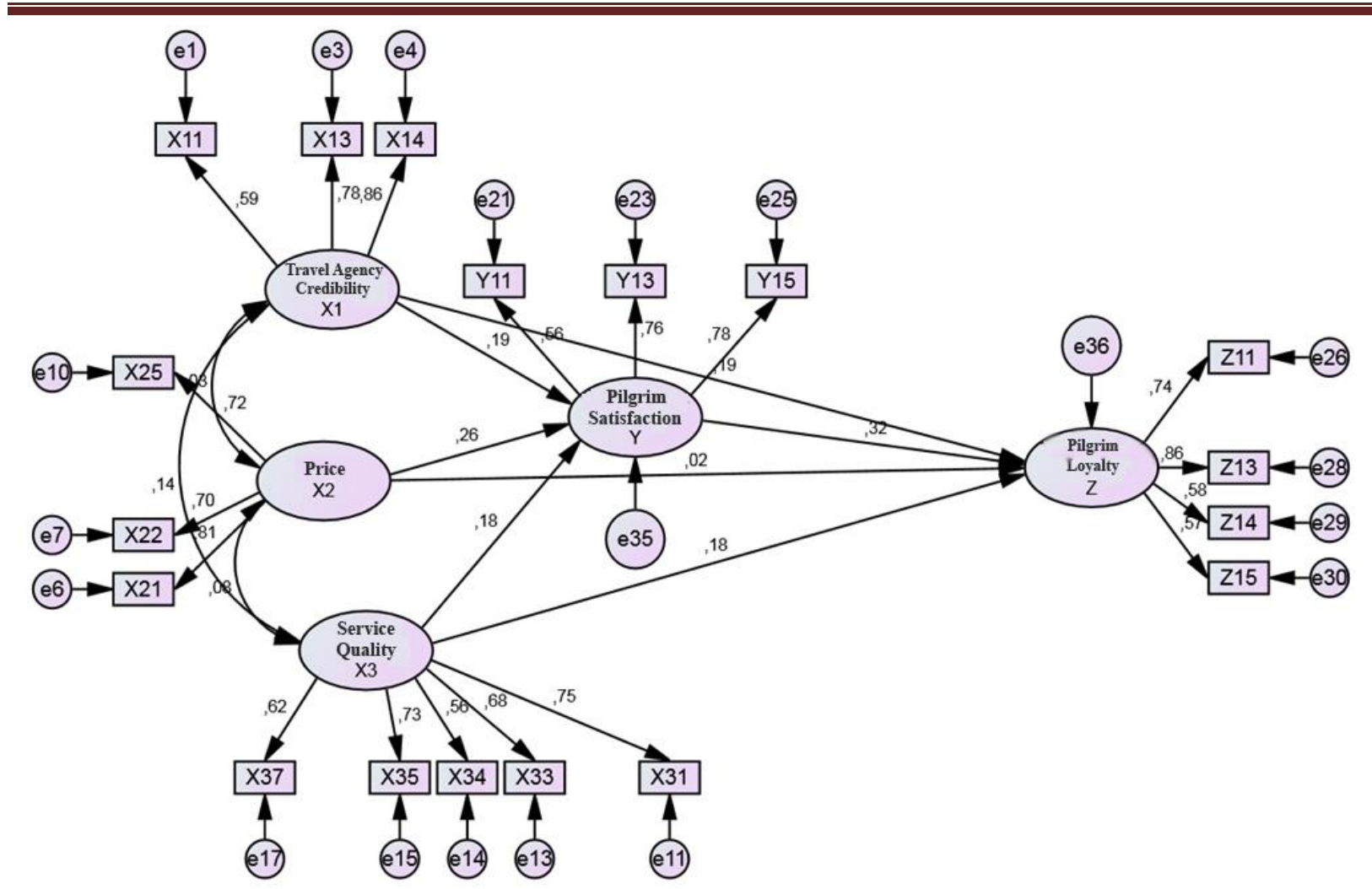

Figure 2. SEM Analysis Results

The results of testing by Amos on the full model for testing hypotheses after passing through SEM assumptions, more clearly it can be seen in the following table:

Table 1. Hypothesis Test Result

\begin{tabular}{|c|c|c|c|c|c|c|c|}
\hline & & & Estimate & \begin{tabular}{|l|} 
Etd \\
Estimate
\end{tabular} & s.E. & C.R. & \\
\hline $\begin{array}{ll}\text { Pilgrim__ }_{\text {_Y }} & \text { Satisfaction } \\
\end{array}$ & $\mid<--$ & Travel_Agent_Credibility_X1 & .160 & .191 & .076 & 2.110 & .035 \\
\hline $\begin{array}{ll}\text { Pilgrim_}_{-} & \text {Satisfaction } \\
\text { _Y }\end{array}$ & |<-- & Price_X2 & .173 & .257 & .063 & 2.764 & .006 \\
\hline $\begin{array}{ll}\text { Pilgrim__ }_{\text {_Y }} & \text { Satisfaction } \\
\end{array}$ & |<--- & Service quality_X3 & .138 & .177 & .070 & 1.970 & .049 \\
\hline Pilgrim Loyalty_Z & $<--$ & Price_X2 & .025 & .025 & .086 & .294 & .768 \\
\hline Pilgrim Loyalty_Z & $<--$ & Pilgrim_Satisfaction_Y & .478 & .317 & .152 & 3.146 & .002 \\
\hline Pilgrim Loyalty_Z & $<---$ & Service quality_X3 & .217 & .184 & .099 & 2.189 & .029 \\
\hline Pilgrim Loyalty_Z & $<---$ & Travel_Agent_Credibility_X1 & .241 & .191 & .107 & 2.246 & .025 \\
\hline
\end{tabular}

Source: Primary Data, 2019 (processed) 


\section{International Journal of Business Management and Economic Review}

Vol. 3, No. 02; 2020

ISSN: 2581-4664

From the test results in the above table it can be seen that:

1. Hypothesis 1 test result namely the effect of travel agent credibility on satisfaction has a Critical Ration (C.R) value of 2.110 at a significant level of $0.035<0.05$, thus it reveals that the Ha hypothesis is accepted and Ho is rejected. In other words, the credibility of a travel agent has a significant effect on the satisfaction of pilgrims. This resultis supported by research conducted by(Halim \& Suryani, 2013); (Ghorban \& Tahernejad, 2012).

2. Furthermore, the result of the hypothesis 2 shows that the price variable on satisfaction has a Critical Ration (C.R) value of 2.764 at a significant level of $0.006<0.05$, thus it explains that the Ha hypothesis is accepted and Ho is rejected. In other words the price has a significant influence on the satisfaction of pilgrims. This resultissupported by research conducted by(Calisir, Basak, \& Calisir, 2016); (Koklic, Kukar-Kinney, \& Vegelj, 2017); (Djumarno, Anjani, \& Djamaluddin, 2018); (Rizal, Adam, \& Ibrahim, 2017); (Jiang \& Zhang, 2016).

3. Hypothesis 3 test result shows that the influence of service quality variables on satisfaction has a Critical Ration (C.R) value of 1.970 at a significant level of $0.049<0.05$, thus it describes that the Ha hypothesis is accepted and Ho is rejected. In other words the quality of service has a significant influence on the satisfaction of pilgrims. This resultissupported with the research conducted by(Lubis \& Utami, 2015); (Calisir et al., 2016); (Hermawan et al., 2017); (Koklic et al., 2017); (Jiang \& Zhang, 2016); (Almaamari \& Abdulrab, 2017); (Kim \& Kim, 2016); (Kasiri, Teoh, Sambasivan, \& Sidin, 2017).

4. Hypothesis 4 test result shows that the influence of satisfaction variables on the loyalty of pilgrims has a value of C.R 3.146 at a significant level of $0.02<0.05$, thus it shows that there is an influence of satisfaction on the loyalty of pilgrims. In other words, satisfaction has a significant effect on the loyalty of pilgrims to PT. Al-Mabrur Aceh. This resultis supportedwith the results of research conducted by(Zhou, Wang, Shi, \& Zhang, 2018)which stated that, customer satisfaction appears as the strongest predictor of customer loyalty. The findings of other researchers also proved that satisfaction affects customer loyalty(Mahmud, Jusoff, \& Hadijah, 2013); (Chotivanich, 2014); (Kasiri et al., 2017); (Kim \& Kim, 2016); (Almaamari \& Abdulrab, 2017); (Djumarno et al., 2018); (Hermawan et al., 2017); (Lubis \& Utami, 2015).

5. Hypothesis 5 test result shows that the influence of the travel agent credibility variable on the loyalty of pilgrims has a Critical Ration (C.R) value of 2,246 at a significant level of $0.025<0.05$, thus it can be stated that the influence of travel agent credibility on the loyalty of pilgrims. In other words, the credibility of a travel agent has a significant effect on the loyalty of pilgrims to PT. Al-Mabrur Aceh. This result is consistent with the results of several previous studies showed that credibility is the main driver in creating and maintaining customer loyalty(Bachri et al., 2016); (Ghorban \& Tahernejad, 2012).

6. Hypothesis 6 test result shows that the effect of price variables on the loyalty of pilgrims has a C.R value of 0.294 at a significant level of $0.768>0.05$, thus it indicates that there is no effect of price on pilgrim loyalty. In other words that the price does not have a significant effect on the loyalty of pilgrims at PT. Al-Mabrur Aceh. This resultis rejected with the research conducted by (Adam \&Michael, 2010); (Toro, 2012); (Jiang \& Zhang, 2016); (Djumarno et al., 2018); (Hermawan et al., 2017); (Rizal et al., 2017). And reject the results of research conducted by(Basir, Modding, Kamase, \& Hasan, 2015)and(Rahyuda \& Atmaja, 


\section{International Journal of Business Management and Economic Review}

Vol. 3, No. 02; 2020

ISSN: 2581-4664

2011)which states that price does not have a positive and significant effect on customer loyalty.

7. The result of hypothesis 7 shows that the influence of service quality variables on the loyalty of pilgrims has a C.R value of 2.189 at a significant level of $0.029<0.05$, thus it states that there is an influence of service quality on pilgrim loyalty. In other words, service quality has a significant effect on the loyalty of pilgrims to PT. Al-Mabrur Aceh. This resultis supported by research conducted by; (Kasiri et al., 2017);(Kim \& Kim, 2016);(Almaamari \& Abdulrab, 2017);(Jiang \& Zhang, 2016);(Hermawan et al., 2017);(Lubis \& Utami, 2015);(Calisir et al., 2016)and(Mahmud et al., 2013)which states that service quality has a positive and significant effect on customer satisfaction.

After proving the direct influence hypothesis, the following results of the indirect effects are presented as follow:

1. In hypothesis 8 , that is the satisfaction mediates the effect of travel agent credibility on the loyalty of pilgrims, the sobel test results t-statistics $1.74<1.96$ and p-value of $0.080>0.05$. The resultexplains the hypothesis 8 is accepted, the satisfaction variable fully mediates (full mediation) the relationship between the credibility of the travel agent and the loyalty of pilgrims to PT. AL-Mabrur Aceh.

2. In hypothesis 9 , that is satisfaction mediates the effect of prices on the loyalty of pilgrims, the sobel test obtained results the t-statistics 2.06> 1.96 and p-value of $0.039<0.05$. These results indicate accepting the hypothesis that states satisfaction mediates the price relationship with the loyalty of pilgrimsat PT. Al-Mabrur Aceh, as a partial mediation.

3. In hypothesis 10 , namely satisfaction mediates the effect of service quality on pilgrim loyalty, the sobel test obtained a result of t-statistics $1.67<1.96$ and p-value of $0.09>0.05$. These results indicate accepting the hypothesis that satisfaction mediates the relationship of service quality with the loyalty of pilgrims at PT. Al-Mabrur Aceh, as a full mediation.

Then the moderation effect is tested as shown in the table below:

Tabel 2.NilaiEstimasiUjiModerasi

\begin{tabular}{|l|l|l|c|c|c|c|}
\hline & & & Estimate & S.E. & C.R. & P \\
\hline Pilgrim Loyalty_Z & $<---$ & Travel_Agent_Credibility_X1 & .351 & .078 & 4.515 & $* * *$ \\
\hline Pilgrim Loyalty_Z & $<---$ & Service quality_X3 & .318 & .073 & 4.387 & $* * *$ \\
\hline Pilgrim Loyalty_Z & $<---$ & Mutawwif_M & .416 & .100 & 4.152 & $* * *$ \\
\hline Pilgrim Loyalty_Z & $<---$ & Interaction_1 & .083 & .056 & 1.463 & .143 \\
\hline Pilgrim Loyalty_Z & $<---$ & Interaction_2 & -.055 & .054 & -1.022 & .307 \\
\hline
\end{tabular}

Source: Primary Data, 2019 (processed)

Based on the results of the above moderation tests for two moderation hypotheses can be explained as follows:

1. In hypothesis 11, Mutawwif moderates the influence of Travel Agent Credibility on Pilgrim Loyalty, the travel agent credibility variable has a significant effect on the loyalty of pilgrims with a significant value of 0.000 , then moderation (mutawwif) significantly influences the Pilgrim loyalty variable with a significant value of 0,000 while the variable variable influences pilgrim loyalty. The interaction $(\mathrm{X} * \mathrm{M})$ did not significantly influence 


\section{International Journal of Business Management and Economic Review}

Vol. 3, No. 02; 2020

ISSN: 2581-4664

the loyalty of the Pilgrim with a significant level of 0.148 greater than 0.05 . Thus it is considered a Predictor of Moderation (Predictor Variable Moderation). This means that the mutawwif variable plays a role as a predictor variable in the established relationship model. The estimated value for interaction 1 is 0.083 , which corresponds to a positive level. Thus it conlcudes that the role of mutawwif can strengthen the relationship between quality of service to the loyalty of pilgrims to PT. Al-Mabrur Aceh.

2. In hypothesis 12 , namely Mutawwif moderates the influence of Service Quality on Pilgrim Loyalty, the service quality variable significantly affects the loyalty of pilgrims with a significant value of 0,000 , then moderating variables (mutawwif) significantly influence the Pilgrim loyalty variable with a significant value of 0,000 while the Interaction variable (Interaction variable) $\mathrm{X} * \mathrm{M}$ ) does not significantly affect the loyalty of Jamaat with a significant level of 0.309 greater than 0.05. Thus it is considered a Predictor of Moderation (Predictor Variable Moderation). This means that the mutawwif variable plays a role as a predictor variable in the established relationship model. The estimated value for interaction 2 is -0.055 which is at a positive level. Thus it describes that the role of mutawwif can weaken the relationship between service quality and the loyalty of pilgrims to PT. AlMabrur Aceh.

\section{CONCLUSION}

The resulsproves that travel agent credibility has a significant effect on pilgrim satisfaction, price has a significant effect on pilgrim satisfaction, service quality has a significant effect on pilgrim satisfaction, satisfaction has a significant effect on the loyalty of pilgrims, travel agent credibility has a significant effect on pilgrim loyalty, price has no significant effect on pilgrim loyalty, Service quality has a significant effect on pilgrim loyalty, there is an indirect effect of travel agent credibility on the loyalty of pilgrims through the satisfaction of pilgrims, on the indirect effect of prices on the loyalty of pilgrims through pilgrimage satisfaction, there is an indirect influence on the quality of service of pilgrims loyalty through pilgrim satisfaction, andMutawwif becomes a predictor that moderates the effect of the travel agent credibility and service quality of the loyalty of pilgrims at PT. Al-Mabrur Aceh. These findings contribute to the renewal of the causality theories and are useful as a basis for the development of advanced research models. The novelty of the research lies in the combination of models of influence between variables from previous studies, and with a new object. The limitation of the study lies in the number of variables.

This research is also useful for practitioners, especially the object of research. Several research implications can be mapped. The leadership of PT. Al-Mabrur needs to hone the ability of Travel Agents to add to attract the attention of pilgrims of trust so that what is conveyed in accordance with reality. In addition, fast response to complaints from pilgrims during the trip to return also really needs to be improved.

\section{REFERENCES}

Adams, J. E., Highhouse, S., \& Zickar, M. J. (2010). Understanding General Distrust of Corporations. Corporate Reputation Review, 13(1). https://doi.org/10.1057/crr.2010.6

Almaamari, Q., \& Abdulrab, M. (2017). Factors Affecting on Customer Loyalty in Service Organizations. International Journal of Energy Policy and Management, 2(5), 25-31. 


\section{International Journal of Business Management and Economic Review}

Vol. 3, No. 02; 2020

ISSN: 2581-4664

Bachri, N., Lubis, A. R., Nurdasila, \& Majid, M. S. A. (2016). Credibility and Consumer Behavior of Islamic Bank in Indonesia: A Literature Review. Expert Journal of Marketing, 4(1), 20-23.

Basir, M., Modding, B., Kamase, J., \& Hasan, S. (2015). Effect of Service Quality, Orientation Services and Pricing on Loyalty and Customer Satisfaction inMarine Transportation Services. International Journal of Humanities and Social Science Invention, 4(6), 1-6.

Calisir, N., Basak, E., \& Calisir, F. (2016). Key drivers of passenger loyalty: A case of Frankfurt-Istanbul flights. Journal of Air Transport Management, 53, 211-217. https://doi.org/https://doi.org/10.1016/j.jairtraman.2016.03.002

Chotivanich, P. (2014). Service Quality, Satifaction, and Customer Loyalty in a Full-Service Domestic Airline in Thailand. International Journal of Arts \& Sciences, 7(3), 161-169.

Djumarno, Anjani, S., \& Djamaluddin, S. (2018). Effect of Product Quality and Price onCustomer Loyalty through Customer Satisfaction. International Journal of Business and Management Invention, 7(8), 13-20.

F. Hair Jr, J., Sarstedt, M., Hopkins, L., \& G. Kuppelwieser, V. (2014). Partial least squares structural equation modeling (PLS-SEM) An emerging tool in business research. European Business Review, 26(2), 106-121.

Ghorban, Z. S., \& Tahernejad, H. (2012). A Study on Effect of Brand Credibility on Word of Mouth: With Reference to Internet Service Providers in Malaysia. International Journal of Marketing Studies, 4(1), 26-37. https://doi.org/10.5539/ijms.v4n1p26

Griffin, J. (2005). Customer Loyalty: Menumbuhkan \& Mempertahankan Kesetiaan Pelanggan. Jakarta: Erlangga.

Hair, J. F., Hult, G. T. M., Ringle, C., \& Sarstedt, M. (2016). A Primer on Partial Least Squares Structural Equation Modeling (PLS-SEM) (2nd ed.). Thousand Oaks: Sage Publications, Inc.

Halim, C. N., \& Suryani, T. (2013). Pengaruh Keramahan, Kredibilitas Dan Citra Karyawan Terhadap Kedekatan Karyawan Dan Kepuasan Nasabah Produk Tabungan Bank Konvensional Di Surabaya. Journal Business and Banking, 3(1), 81-92. https://doi.org/http://dx.doi.org/10.14414/jbb.v3i1.256

Hermawan, B., Basalamah, S., Djamereng, A., \& Plyriadi, A. (2017). Effect of Service Quality and Price Perception on Corporate Image, Customer Satisfaction and Customer Loyalty among Mobile Telecommunication Services Provider. IRA-International Journal of Management \& Social Sciences, 8(1), 62-73. https://doi.org/10.21013/jmss.v8.n1.p7

Jauhary, R. (2014). Buku Menjadi Muthawif Anda Di Tanah Suci Panduan Perjalanan Dari Tanah Air Ke Tanah Suci. Medan: Nur Cahaya Ilmu.

Jiang, H., \& Zhang, Y. (2016). An investigation of service quality, customer satisfaction and loyalty in China's airline market. Journal of Air Transport Management, 57, 80-88. https://doi.org/https://doi.org/10.1016/j.jairtraman.2016.07.008

Kasiri, L., Teoh, K., Sambasivan, M., \& Sidin, S. M. (2017). Integration of standardization and customization: Impact on service quality, customer satisfaction, and loyalty. Journal of Retailing and Consumer Services, 35, 91-97. https://doi.org/10.1016/j.jretconser.2016.11.007

Kim, S.-B., \& Kim, D.-Y. (2016). The impacts of corporate social responsibility, service quality, and transparency on relationship quality and customer loyalty in the hotel industry. Asian 
Vol. 3, No. 02; 2020

ISSN: 2581-4664

\begin{tabular}{llllll}
\hline \hline $\begin{array}{l}\text { Journal of Sustainability and } \\
\text { https://doi.org/10.1186/s41180-016-000 }\end{array}$ & Social & Responsibility, & l(1), & $1-17$.
\end{tabular}

Koklic, M. K., Kukar-Kinney, M., \& Vegelj, S. (2017). An investigation of customer satisfaction with low-cost and full-service airline companies. Journal of Business Research, 80, 188196. https://doi.org/https://doi.org/10.1016/j.jbusres.2017.05.015

Kotler, P., \& Keller, K. L. (2009). Manajemen Pemasaran (12th ed.). Jakarta: PT. Indeks.

Kotler, P., \& Keller, K. L. (2012). Marketing Management (14th ed.). London, UK: Pearson Education.

Kotler, P., \& Keller, K. L. (2018). Marketing Management, Global Edition (15th editi). Harlow, United Kingdom: Pearson.

Lubis, A. R., \& Utami, S. (2015). Dimensions of Services Quality Affect the Satisfaction and Their Implication on Loyalty ( A Survey of Private College Students in Banda Aceh City ). European Journal of Business and Management, 7(33), 168-173.

Mahmud, A., Jusoff, K., \& Hadijah, S. (2013). The Effect of Service Quality and Price on Satisfaction and Loyalty of Customer of Commercial Flight Service Industry. World Applied Sciences $\quad$ Journal, $354-359$. https://doi.org/10.5829/idosi.wasj.2013.23.03.13052

Oh, H., Jeong, M., \& Baloglu, S. (2013). Tourists' adoption of self-service technologies at resort hotels. Journal of Business Research, 66(6), 692-699. https://doi.org/10.1016/j.jbusres.2011.09.005

Parasuraman, A. P., Zeithaml, V. A., \& Berry, L. L. (1988). SERVQUAL: A multiple- Item Scale for measuring consumer perceptions of service quality. Journal of Retailing, 64(1 Spring), $12-40$.

Priansa, D. J. (2017). Prilaku Konsumen dalam persaingan bisnis kontenporer. Bandung: Alfabeta.

Rahyuda, I. K., \& Atmaja, N. P. C. D. (2011). The influence of price fairness, corporate image to the satisfaction and loyalty of Gia domestic flight users in Denpasar. EKUITAS (Jurnal Ekonomi Dan Keuangan), https://doi.org/http://dx.doi.org/10.24034/j25485024.y2011.v15.i3.374

Ramli, A. H., \& Sjahruddin, H. (2015). Building Patient Loyalty in Healthcare Services. International Review of Management and Business Research, 4(2), 391-401.

Rizal, F., Adam, M., \& Ibrahim, M. (2017). Effect of Price, Design and Location on Decision of Purchase and Its Implication on Customer Satisfaction. International Journal of Economics, Commerce and Management, $V(12), 345-353$.

Shimp, T. A. (2013). Advertising, Promotion, adn Other Aspect of Integrated Marketing Communivations. In Journal of Chemical Information and Modeling (7th Editio, Vol. 53). https://doi.org/10.1017/CBO9781107415324.004

Silva, R. V. Da, \& Alwi, S. F. S. (2008). Online brand attributes and online corporate brand images. European Journal of Marketing, 42(9), 1039-1058. https://doi.org/https://doi.org/10.1108/03090560810891136

Simamora, B. (2004). Riset pemasaran : falsafah, teori dan aplikasi. Jakarta: Gramedia Pustaka Utama.

Sunyoto, D. (2012). Dasar-dasar Manajemen Pemasaran: konsep, Strategi, dan Kasus. Yogyakarta: Caps. 
International Journal of Business Management and Economic Review

Vol. 3, No. 02; 2020

ISSN: 2581-4664

Tjiptono, F. (2017). Strategi pemasaran (4th ed.). Jakarta: Andi.

Wijaya, T. (2018). Manajemen Kualitas Jasa (Ed. 2). Jakarta: Indeks.

Zeithaml, V., Bitner, M. J., \& Gremler, D. (2018). Services Marketing: Integrating Customer Focus Across the Firm (7th ed.). New York: McGraw-Hill.

Zhou, R., Wang, X., Shi, Y., \& Zhang, R. (2018). Measuring e-service quality and its importance to customer satisfaction and loyalty: an empirical study in a telecom setting. Electronic Commerce Research, 19(11). https://doi.org/10.1007/s10660-018-9301-3 